\title{
The International and
}

\section{Comparative Law Quarterly}

\section{VOLUME 9}

1960

William S. Hein \& Co., Inc.

Buffalo, New York

2003 
(1) British Institute of International and Comparative Law 1960. Published by Oxford University Press.

All rights reserved

This book has been digitally archived, to maintain the quality of the original work for future generations of legal researchers, by William S. Hein \& Co., Inc.

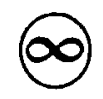

This volume is printed on acid-free paper by William S. Hein \& Co., Inc. 


\title{
Society of Comparative Legislation and International Law
}

\author{
CHAIRMAN OF THE EXECUTIVE COMMITTEE : \\ The Rr. How. Lord Densixo
}

COUNCIL :

M. Marc Ancel, Secrétaire Général de la Saclété de Législation Comparée.

Sir W. Bernard Blatch.

The Rt. Hon. Vlocount Bruce, c.r., x.c.

Sir John A. Calder, z.c.s.o.

Sir Cecil T. Carr, r.c.8., Q.c., w.D.

The Hon. Mr. Justice Centlirres, formerly Chlef Justice of South Africa.

Dr. Futting Tien-Hsi Cheng, LL.D.

Professor G. C. Cheshire, D.c.In, r.8.A.

J. Christie. Esq., c.ss.o., us.

The Rt. Hon. Sir Winston S. Churchill, x.o., o.s., C.H., M.r.

The Rt. Hon. Lord Cohen.

Professor Rene David.

Clement Davles, Esq., Q.c., x.P.

The Rt. Hon. Lord Denning.

The Rt. Hon. Sir Owen Dixon, Chief Justice of Australia.

Sir Oscar Dowson, c.в.x., formerly Legal Adviser to the Home Oftice.

Sir Harold Duncan, x.c.s.o., a.c., formerly Legal Adviser to the Colonial Office and the Dominions Office.

Phanor J. Eder, Esq.

The Rt. Hon. H. V. Evatt, D.LITT., LLd.

The Hon. R. Feetham, css.o., formerly Judge of the Appellate Dlotsion of the Supreme Court of South Africa.
E. G. M. Fletcher, Esq., LI.D., 8x.?.

Sir Lancelot Graham, K.c.s.r., x.c.1.E, formerly Secretary to the Government of India in the Legdalative Department.

F. N. Keen, Esq.

The Hon, Mr. Justice Korsah, c.e.s.

The Hon. Rlcardo de Labougle, un.D. Judge Learned Hand.

Sir Lynden Macassey, r.B.z., a.c.

Sir Henry MacGeagh, o.c.v.o, E.c.s, k.B.E., Q.C.

The Rt. Hon. Vincent Massey, Governor-General of Canada.

The Rt. Hon. Lord Reld of Drem.

The Rt. Hon. T. Rinfret, formerly Chief Justice of Cansda.

Sir J. S. Risley, к.c.x.o., c.в., Q.c, formerly Legal Adviser to the Colonial Office and Dominlons Office.

The Hon. Mr. Justice Sandstrom.

Sir John Houldsworth Shaw, formerly Solicitor to the Inland Revenue.

The Hon. Mr. Justice Fabre-Surveyer, Judge of the Supreme Court, Quebec.

The Rt. Hon. Lord Thomson.

Sir Geoffrey Vickers, v.c.

Professor E. C. S. Wade, LL.D., Ps.A, Downing Professor of the Laws of England.

Professor B. A. Wortley, o.B.E., LLD. 
EXECUTIVE COMMITTEE :

Sir W. Bernard Blatch.

- Professor G. C. Cheshire, D.c.n., P.s.L.

The Rt. Hon. Lord Cohen.

J. Cohen, Eeq., Hon. Treasurer.

-Dr. C. J. Colombos, a.c.

'The Rt. Hon. Lord Denning, Chairman.

- Sir Harold Duncan, x.c.x.o., a.c.

Sir Gerald Fitemaurice, k.c.x.n.

- Professor R. H. Graveson, IL-D, PH.D., 8.J.D.

-Professor C. J. Hamson.

'Professor R. Y. Jennings, x.A., IL.B. F. N. Keen, Esq.

Wullam Latey, Esq., a.c.

- Profesuar F. H. Lawbon, o.c.L.
R. A. Lynex, Esq.

Sir Lynden Macassey, x.B.E., e.c.

-N. S. Marsh, Esq.

Richard O'Sullivan, Esq., a.c.

Professor Sir David Hughes Parry, o.c., D.c.L., IL.D.

Sir Kenneth Roberts-Wray, x.c.m.o.

"Dr. G. Schwarzenberger, PH.D, Da.sun.

-Dr. C. Sluzewaki.

Professor E. C. S. Wade, Ll.D., F.B.A.

-Protessor C. H. M. Waldock, c.s.o., O.B.E, Q.C., D.C.L.

"E. H. Wall, Esq., r.D, Hon. 8eorstary.

-R. O. Wilberforce, Esq., c.M.o., 0.B.x., a.c.

- Professor B. A. Wortley, o.B.r., Lz.D.

Those marked * are members of the Editorial Sub-Committee

The Bditors and the members of the Editorial Bub-Commilles do not hald themselves in any roay responsible for the vicws expressed by contributors. 


\section{INDEX OF CONTRIBUTORS OF ARTICLES AND NOTES}

Agrh, Paur, Reform of the Austrian Adoption Legislation

481

Relations between the German Federal Republic and the German Democratic Republic

688

642

Axpeasox, J. N.D., A Laf or Persokar Status ron Iraq

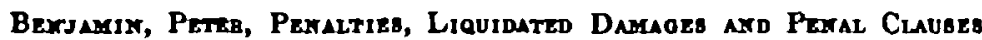
is Commencial, Contracty \& A Comparative Study of Exolieh axo Continental Lat

Bowetr, D. W., The Secord Umited Natroxs Compenemce ox the Lat or THE Ses

Cohx, E. J., The Genent Atronsey-Expeniraces with a Urified ProFEsior (I)

Parnab, L, Organisation and Activity of the Court of Arbitration of the Hungarian Chamber of Commerce

Frinmax, G. H. L, Choice or Law Govenuiva the Teatamertaex Exen-

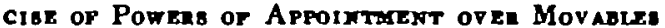

Gravzsox, R. H, The Future of the Nigertan Legal Profession

An Index to Foreign Legal Perlodicals

127

126

Grodecki, J. K., State Ecomomic Angitration in Poland

177

Jeaney, J. H., The Structune, Coxposition ard Juaibdiction of Counte axd Autronities Exponcino the Cajuinal Lat in British Aprican Tenaitonizo

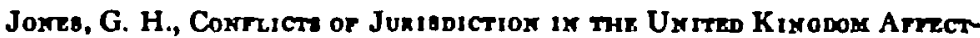
ixo Childass

Labox, D., A leoal. Coxcept of Mabaiage ayd Divolce (A Comparative Study ix Polieh and Westean Fayily Law)

Lauterpacht, E., Coxtemporanx Practice of the Uxited Kimodom ix THE FizLd OP I MTERxational Law-SURvex akd Comprert. VIII

Riveb Boundaites Lroal Agrecto or me Shatt-alAnas Fromtier

Maxz, P. A., Sovereign or Fisc?

Moroay, Glend G, The "Proposal" of the Soviet Plocunatoe 191

Mugray, D. E., Sale in Mabxet Opeat 24

Noxss, G. D., Irish Law ix Exalisy Courts 664

O'Hroorsu, PaUh, Extradition within the Commonwealth 486

The Irish Maritime Jurisdiction Act, 1959

Padwa, David J., Submanige Boumdarizg 628 
viii

Patey, Jaceues, Recext Rrmomb in French Crimixal Law axd Procenure

Reegf, Willis L M., Contracts and the Restatement of Conflict op Lats, SEcoxd

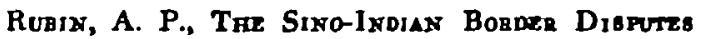

Scindjtrhorp, C M., Colloquiom on some Problems of Non-Performance and Force Majoure in International Contracts of Sale

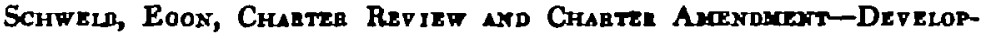
SIENTS IN 1958 AND 1859

Intzanational Confentrose on Human Riohts

Srmmond, K. R., Implied Waiver of Immunity: Permissible Counterclaim against a Sovereign Plaintiff

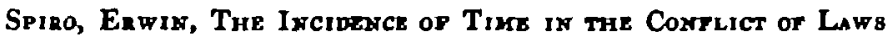

Tocrea, Sour, The Legitimacy Act, 1959-Putative Marriages Resurrected?

Vas Deb Buaor, J. G., Sale in Market Opert: A Further Comment 


\section{INDEX OF CASES NOTED}

(Names of contributors ars insorted in brackets)

Adams o. Natlonal Bank of Greece (Michael Mano) . . . . . 698

R. Caborn-Waterfield (Paul O'Higgins) . . . . . . . . . 498

Callwood o. Callwood (L. W. S. Upton) . . . . . . . . . 514

Hil ஏ. Hll (P. R. H. Webb) . . . . . . . . . . 129

1. R. C. o. Collco Dealings, Ltd. (Paul O'Higgins) . . . . . 199

Ohochuku v. Ohochuku (E. Griew) . . . . . . . . 508

Phrantres o. Argenti (G. H. Jones) . . . . . . . . 808

Ratan v. Sunder (J. D. M. Derrett) . . . . . . . . 610

Ross-Smith o. Ross-Smith (P. R. H. Webb) . . . . . . . 707

Re Shuter (Paul O'Higgins) . . . . . . . . . . . 141

R. Shuter (No. 2) (Paul O'Higgins) . . . . . . . . . . . 141

Tomkinson v. First Pennsylvania Banking Trust Compang (Valentine L.

Korah) . . . . . . . . . . . . . . 700

Further Comment (R. H. G.) . . . . . . . . . . 704 


\section{INDEX OF BOOK REVIEWS}

Allott, A. Essays in African Law, with special reference to the Law of Ghana

Anderson, J. N. D. Islamic Law in the Modern World 169

$\begin{array}{ll}\text { Annual Survey of South African Law, } 1968 & 157\end{array}$

Aron, Raymond. France-The New Republle 787

Birks, Michael. Gentlemen of the Law 742

Blagojerich, B. T. Bibllographle Jurdique Yougoslave 161

Bohmer, A. Legal Sources and Bibliography of Crechoslovakda 161

Brusiln, Otto. Zum Ehescheidungsproblem 188

Bystrfcky, R. Zaklady Mealnarodniho Prava Soukromcho (Elements of Private International Law)

Coing, $H$. and Kranstein, $H$. Die Nennwertlose Aktie als Rechtsproblem

Dabin, Lkon. Fondement, du Drolt Camblaire Allemand

Drake, Howard. Index to Forelgn Legal Periodicals 352

Drobnig, Ulrich. Haftungsdurchgrif bel Kapitalgesellschaften 725

Elliott, R. C. Legal Forms in Engtish and Afrikaans 167

E४rsi, G. Acta Juridica Academise Scientlarum Hungaricae, $1969 \quad 171$

Esser, Albert. Die Ehrenstrafe 152

Georgakopoulos, L. N. Die Grundung der Aktiengesellschaft 718

Goodhart, A. L. The Migration of the Common Law 622

Götz, H. N. Das Seefrachtrecht der Haager Regeln nach AngloAmierikanlscher Praxis

Gsovski, V., and Grybowski, K. Government, Law and Courts in the Sorlet Union and Eastern Europe 716

Hall, C. G. Massdorp's Institute of South African Law, Vol. II, Law of Things

Hart, H. L. A., and Aonort, A. M. Causation in the Law 858

Haskins, G. L. Law and Authority in Early Massachusetts 786

Heinisch, M. Beendigung und Nichtigkeit der Adoption 721

Heix, R. Das Fremde Offentliche Recht in Internationalen-Kolitionsrecht

Index to Forelgn Legal Periodicals, Vol. 1, No. $2 \quad 735$

Inter-American Law Review 155

Jeannot, C. La Notion d'Interets Personnels et l'Ecrivain 716

Jullitot de la Morandiere, L, et al. Etudes de Drolt Contemporain 172

Kalnokl, A. Legal Sources and Bibliography of Hungary 151

Keeton, G. W., and Schwarzenberger, G. Current Legal Problems, 1959166

Kersell, J. E. Parliamentary Supervislon of Delegated Legislation 740

Kiralfy, A. K. R. British Legal Papers, Brussela Congreas of Comparative Law, 1958

Law and Legislation in the German Democratic Republic 178

Lloyd, D. Introduction to Jurisprudence B47

Ludwicrak, W. Miedzynarodowe Prawo Prywatne (Private International Law)

MeCracken, J. L. Representative Government in Ireland. A Study of Dáll Elreann, 1819-48 
Markianos, J. Die Ubernahme der Haager Regeln in die nationalen Gesetee tober die Vehfracliterhaftung

Morris, J. H. C. Cases on Private International Law 619

"Oxford Lowyer," The 174

Parisi, G. A. Piccola Enclelopedia Gluridica 165

Phillips, O. Hood. A First Book of English Law (4th ed.) 788

Polay, E. Jógrendszerek az ókori Romában $\quad \mathbf{7 1 0}$

Praybylowskl, K. Z Problematykj stosowanla obcych norm kolkyjnych 619

Rühl, W. Fremde Einfluse im modernen Japanischen Recht 172

Ross, Alf. On Law and Justice 163

Saint-Gal, Yves. Protection et défense des Marques de Fabrique et Concurrence Deloyale $\quad 848$

Samson, B. Grundzlige des mitteldeutschen Wirtschaftsrechts $\quad 714$

Schlesinger, R. B. Comparative Law 724

Schmidt, F. Scandinavlan Studies in Law 164

Serick, Rolf. Durchgriffsprobleme bei Vertragsstörungen 169

Sommerich, Otto C., and Busch, Benjamin. Foreign Law (A Guide to . Pleading and Proof) 168

Sotlropoulos, P. Die Haftung für die Hilfspersonen der Schiffsbesatzung nach deutschem, franzisischem und englischem Recht TzO

Spiro, Erwin. Law of Parent and Chlld 165

Stason, Estep and Pierce. Atoms and the Law 840

Szirmal, Z., and Korevar,, J. D. The Merchant Shlpping Code of the Soviet Union

United Nations Legal Publications

Vos, W. de. Verrykingsaanspreeklikheld in die Suld-Afrikaanse Reg 160 


\section{SUBJECT INDEX OF ARTICLES, NOTES AND DECISIONS}

\section{PRIVATE INTERNATIONAL LAW}

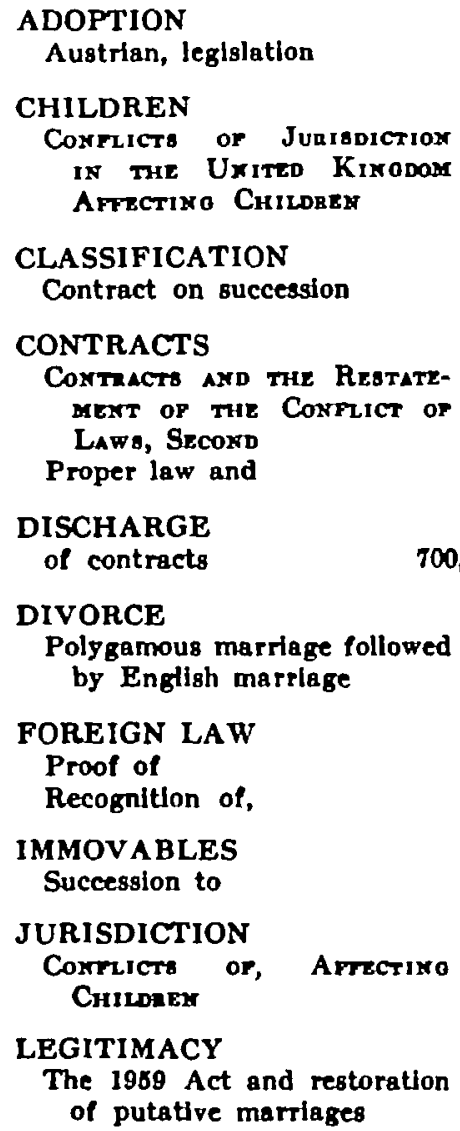

481

15

695

681

700

700,704

LEX LOCI CELEBRATIONIS

and nullity jurisdiction 129, 707

MARRIAGE, polygamous, dirorce and, $\quad 508$ putative, and Legitimacy Act, 1959

\section{MOVABLES}

Chotce of Law ayd Powera or AppoIstmest OVER

NOVATION

and discharge of contracts

NULLITY

700,704

jurisdiction in

129, 707

POWERS OF APPOINTMENT

Chosce of Lat Goversixo

The Tegtamextan Exigcibe of Powegs of Appointment OPEB Mov ables.

514

508

RECOGNITION

of forelgn law

RESTATEMENT, SECOND

CONTIACTS AKD THE

681

SUCCESSION

15 Immovables, to 514

Perbonal law and Hindu $\$ 10$

TIME

919 Is Tie Coxphict of Laws 357

2. COMPARATIVE LAW
AUSTRIA
Reform of the Austrlan Adop- tion Legislation
FRANCE
Penalties and liquidated dam- ages in contracts
Recert Repoms in Faexch Criminal Lat and Proce- nure
Sale in market overt

GERMANY
481 Attorney
Penalties In Contracts
Sale in market overt
HUNGARY
Organisation and Activity of
$610 \quad 417$
the Court of Arbitration of
the Hungarian Chamber of
888 Commerce
40 HAMMURABI, Code of
xiii


INDEX to Poreign Legal
Periodicals

IRAQ

Pergonal Status ix

IRELAND

Iribh Lan in Evoliah Conrto Common Law

Statutory Law

NETHERLANDS

Sale in market overt

NIGERIA

Future of the Nigerian Legal Profession

Non-Performance in International Contracts

Penaltieg-in commercial contracts

542

664

667

574

676

POLAND

Economic Law-State Economic ARAtrantion
POLAND-cont.

Family LAH-Maseiace aNo Divorce in Polish ard Wegtegh Famity Law

Divorce 75

Foundation of Marriage 55

Husband's and wife's rights and duties

Matrimonial property

65

d\&

QUEBEC

Sale in market overt 28

SPAIN

Sale in market overt

\section{UNITED KINGDOM}

Family law: jurisdiction affecting children

U.S.A.

Sale in market overt

U.S.S.R.

Penalties in contracts 620

\section{PUBLIC INTERNATIONAL LAW}

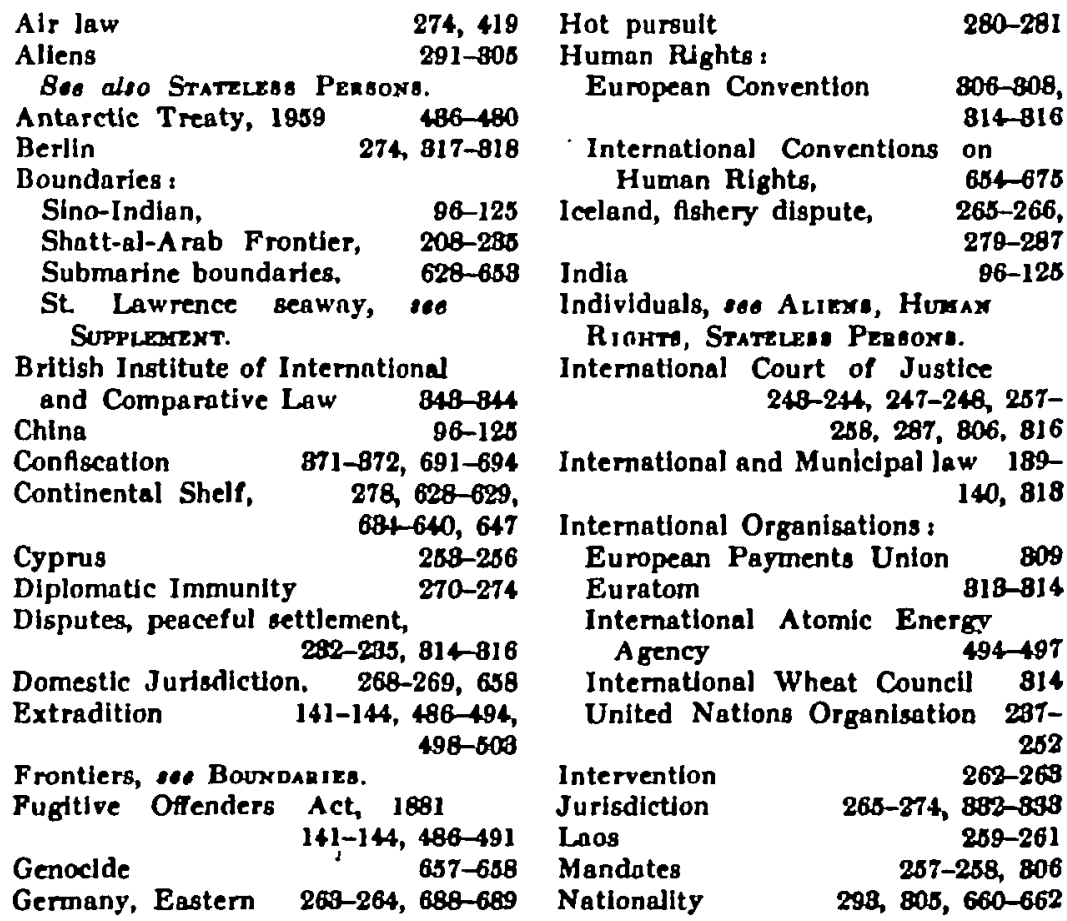


National Waters

Neutrality

Nuclear energy

Occupying forces

Prisoners of war

Protected States

Recognition

Rivers :

River Boundaries: Legal

Aspects of the Shatt-al-

A rab Frontier

208-295

St. Lawrence seaway, sos SUPplenert.

Sea, law of :

Fisherico 276-278, 280, 419-421

Genera Conventions and the

U.S. Senate

$690-691$

lrish Maritime Jurisdiction

Act, 1969 326-894

Second Geneva Conference on the Law of the Sea $416-495$

Submarine boundartes 628-658

Territorial waters

See aloo Contromejtal Shew, Icelaxd, National Watera.

Sino-Indian Border Disputes 96-125

Sovereign immunity

269-270,

884-849

Space law 874

Statelesa persons

State responslbility $288-291,698-694$

State succession
$806,660-662$

264-265, 810
Subjects of International law :

Acquisition of independence 258-

256

Colonles 808

Condominium 258-269, 488-440

States under suzerainty

258

Beo also Ixoividouls, Maydates, Protrcted States.

Sues affair

$288-290$

Territory :

Acquisition 92-125, 486-487, 644-645

Sovereignty over 274-276

gee afoo Bournanies, Contr-

remtal Shel, Natioxal

Water8, Riveab, Sea, Law

of, Space Law, Trayeit.

Thalweg

216-226

Tibet

96-125, 258

Tranuit

275-276

Soo also Sopplemert: St.

Lawnerce Seatrat.

Treaties

808-818

and Municipal Law 189-140, 813,

$814-816,602-608$

Third States 470,478

United Nations Organisation:

Charter Review and Amendment, $1968-69$

287-252

Legal publications $\quad$ 526-629

War

816-818

A rmistlce in LAOS

259-261

Bea aloo Prisonert of War. 